\title{
The Geological Age of the Earliest Palaeolithic Flint Implements.
}

\author{
By J. Reid MoIr.
}

THE investigations which I have carried out in the Ipswich district of Suffolk, and certain discoveries (to be described shortly) made (luring the past year at Mundesley, Norfolk, have impressed upon my mind the possibility that the ordinary platessiform and batiform palæolithic flint implements found usually in river terrace gravels are older geologically than has been generally imagined. This, however, is not altogether an original opinion, as the late Professor James Geikie, F.R.S.,' the late Mr. S. B. J. Skertchly, ${ }^{2}$ and Mr. A.S. Kennard, ${ }^{,}$basing their views upon evidence other than that upon which I rely, arrived at a similar conclusion. $A s$ is well known, it was stated authoritatively many years ago that our English river-valleys containing implementiferous gravel beds were cut through, and are therefore later than the Chalky Boulder-clay. ${ }^{4}$

Now, however, a closer examination, or access to sections not visible years ago, has demonstrated that in the case of the main river-valleys of Suffolk this dictum no longer holds good." Further, it would appear hardly justifiable to assume that because a gravel bed can be shown to have been laid down after the deposition of the Chalky Boulder-clay, the flint implements contained in such a gravel, which are often considerably rolled and older than the bed in which they occur, are, necessarily, to be referred to postChalky Boulder-clay times.

Again, for many years past Continental archæologists and geologists have recognized that the various races of palæolithic man lived in mild epochs intervening between the different glacial episodes, and, as England during the greater part of the palæolithic period was joined to the Continent and experienced probably similar vicissitudes of climate, it would seem unlikely that all the English palæolithic artefacts are post-Glacial.

The discoveries to which I have referred have led me to propose the following table, showing the various prehistoric flint cultures and their relationship to the glacial deposits of East Anglia. I have also ventured to attempt a correlation of these East Anglian glacial deposits with those recognized upon the Continent by Professor Albrecht Penck. ${ }^{6}$ But this is, at present, a tentative correlation,

1 The Great Ice Age, pp. i20-4is.

2 The Geology of the Fenland (Mom. Geol. Surv. (ireat Britain).

" "The Pleistocene Succession in England": Proc. P.S.F.A., rol. ii, pt. ii, pp. $249-67$.

+ Sir J. Prestwich, Phil. Trans., vol. cl, 1869, p. 305.

"Boswell, "The Age of the Suffolk Valleys": Quart. Journ. Geol, Soc., vol. lxix, pp. 581-620.

$\checkmark$ Die Alpen im Eiszeitalter. 
and, further, I would wish it to be clearly understood that the views expressed in this note are based solely upon discoveries made in the Ipswich district, an area with which I am intimately familiar.

Neolithic.-On the high ground near Ipswich a flint arrow-head was found in the surface soil. ${ }^{1}$ In the bottom of the Gipping Valley a chipped and polished flint axe has been discovered recently under 3 to 4 feet of peat surface soil. (Man, in course of publication.)

UpPer Palfolithic: Magdalenian.--No certain traces found, unless a floor in Ivry Street, Ipswich, buried under 2 or 3 fect of stoneless snuff-coloured sand, can be referred to this cultural phase. This floor is situated upon the plateau. ${ }^{2}$

Solutrian.-A patinated and rolled early Solutrian flint blade was found in gravel at the site of the Ipswich Electric Power Station, situated in the bottom of the Gipping Valley.:

Two Early Solutrian blades were found in hill-wash overlying the Aurignacian floor in Messrs. Bolton \& Co.'s brickfield, Henley Road, Ipswich. ${ }^{4}$ This hill-wash was probably laid down during a period of low temperature, and may perhaps be regarded as the equivalent, on the high ground, of the river-gravel in the Gipping Valley containing a Solutrian blade. The period of low temperature responsible for these depositions may have been that known upon the Continent as the Wirm.

AURIgraciax.-A well-marked floor, containing Aurignacian flint implements, covered by the above-mentioned bill-wash, and resting upon loamy sand in Messrs. Bolton \& Co.'s brickfield, Ipswich."

Lower Palgoltinc: Upper Mousterian.-A well-marked floor, containing Upper Mousterian flint implements, generally covered by peat or loamy sand, and resting sometimes upon Chulky Bonlderclay in Messrs. Bolton \& Co.'s brickfield, Ipswich. ${ }^{6}$

? Middle Mousterian.-A floor with ? Middle Mousterian flint implements and abundant remains of reindeer, occurring in loam. and under 4 feet of alluvium and 8 feet of gravel (the deposit containing the Early Solutrian blade above mentioned) at the site of the Electric Power Station, Constantine Road, Ipswich. ${ }^{7}$

Lower Mousterian.-Flint implements found in Chalky Boulderclay at Bolton \& Co.'s brickfield, Ipswich, and Mason's Cement Works, Claydon. ${ }^{*}$

The Chalky Boulder-elay may be referable to the Riss glaciation.

1 Moir, Journ. Roy. Anthr. Inst., vol. xlvii, 1917, pp. $406-\overline{7}$.

$\because$ Moir, Proc. P.S.E.A., rol. i, pt. iv, pp. $475-9$.

"Hancox, Proc. Suff. Inst. Arch. and Nat. Hist., vol. xi, pt. $i$ and pt. ii, fic. 4.

- Moir, Journ. Roy. Anthr. Inst., vol, xlvii, 1917, pp. 46.5-6.

5 Ihid., pp. 367-412.

b Ibid.

: Iroir, Man, vol. xviii, No. 7, .July, 1918.

- Moir, Proc. Suff. Inst. Areh. and Nat. Hist., vol. xvi, pt. ii, pp. 9s-134. 
Acheulean.-Late Acheulean flint implements found by Miss N. F. Layard in a silted-up channel in the plateau at Foxhall Road, Ipswich. ${ }^{1}$ One such specimen (now preserved in the British Iluseum, Bloomsbury), recovered by me on the eastern side of the channel, occurred upon sand overlain by contorted material classed by Boswell as "Upper Glacial "."

Chellian.-Small derived specimens of Chellian, platessiform implements were found in the Middle Glacial Gravel at Bolton and Co.'s brickfield, Ipswich."

This gravel may perhaps be regarded as of Mindel-Riss interglacial age.

The discoveries made upon the Mundesley coast, and further researches carried out this year at Cromer, tend to show that the glacial gravels overlying the Till contain derived Chellian flint implements, and from the finding of certain flakes, etc, in the Cromer Forest Bed it is suggested that this deposit is the real Chellian horizon. The Till and associated beds may possibly represent the depositions of the Mindel glaciation. The Chellian implements may therefore be of Ginz-Mindel interglacial age.

Pre-PALEOSITHIC.- The flint implements found in the detritusbed beneath the Red Crag of Suffolk. ${ }^{4}$ These specimens, which I regard as of pre-Chellian types, are frequently striated. It is possible that these striæ were imposed during the Giinz glaciation (the earliest glacial epoch recognized by Penck), and the large block of darkred porphyry, "weighing about a quarter of a ton," seen by Prestwich to be resting upon the London Clay at the base of the Coralline Crag at Sutton, near Woodbridge," may have been transported by the ice of this glacial episode.

The very primitive edge-trimmed stones, known as "eoliths", occur as deeply iron-stained and rolled derivatives in the Middle Glacial Gravel in Messrs. Bolton \& Co.'s brickfield, Ipswich."

These specimens are regarded as representing the earliest efforts of man to fashion flints, and as being the precursors of the Sub-Red Crag artefacts.'

It is also believed that the Sub-Red Crag rostro-carinate flint implements developed into the earliest platessiform and batiform Chellian implements."

The discovery of Acheulean flint implements at Hoxne ${ }^{3}$ and at Foxhall Road, Ipswich, ${ }^{10}$ orcurring in deposits resting upon Boulder-

1 Journ. Roy. Anthr. Inst, vol. xxxiii, 1903.

2 Proce Geol. Assor, vol xxy, pt. iii, p. 136.

3 Moir, Journ. Rov. Anthr. Inst., vol. xlix, 1919, pp. 74-93.

- Moir, Proc. Prehis. Soc. Last Anglia, vol. i, pt. i, pp. 17-43, and other papers.

The structure of the Craytheds, London, 1871, p. 117 .

6 Moir, Proc. P.S.l..A., vol. i, pt. iii, pp. 307-19.

T Moir, Pre-palceolithio Man, pp. 21-34. Harrison, Ipswich.

Moir, Phil. Trans., B, 1919, p. 209.

y Brit. Assoc. Report, 1896, p. 12.

10 .Journ. Roy. Anthr. Inst., vol. xxxiii, 1903. 


\section{Prof. S. H. Reynolds-Serpentine near Wells, Somerset.}

clay, are of importance in this inquiry (it seems that there are two glacial deposits at the latter place, one above the palæolithic horizon and one below it), and it is suggested that, at both these places, occur patches of a once widespread sheet of glacial clay older than what is known as the Chalky Boulder-clay, and perhaps referable to the Mindel glaciation. The well-known section at High Lodge, Mildenhall, where a Mousterian brick-earth interdigitates with a mass of Chalky Boulder-clay, ${ }^{\prime}$ represents probably a remnant of the Mousterian deposits, many of which were ploughed up by the ice and furnished the implements of this culture found in the Boulder-clay.

Professor J. E. Marr, F.R.S., who has visited Ipswich and seen and examined the evidence at my disposal, permits me to say that he considers a prima facie case has been made out for the above correlation, so far as the deposits of East Anglia are concerned. He considers, however, that the reference of certain deposits to the periods of glaciation upon the Continent requires further investigation. With this conclusion $I$ an in agreement.

\section{On the Occurrence of Picritic Serpentine at Ebbor, near Wells, Somerset.}

By Sidney H. Revrolds, M.A., Sc.D., Professor of Geology in the University of Bristol.

TN October, 1904, Mr. H. E. Balch, of Wells, forwarded some 1 pieces of "trap" from Ebbor to the late Mr. H. B. Woodward, who handed them to Dr. J. S. Flett for examination. At a slightly later date pieces were given to me by Dr. 'T. F. Sibly, who was then at work in the Mendips.

It was at once clear that we had here an ultra-basic rock, and Dr. Flett, whose description will be quoted immediately, pointed out the practical identity of the rock with that from Clicker Tor, Menheniot, Cornwall, whence he believed the specimens had been derived. The rock occurred in the form of small pieces, rarely more than $2 \frac{1}{2}$ inches long, scattered over quite a limited area about a quarter of a mile N.W. of Wookey Hole and due south of Lammas Wood. The very great majority were found in a field due south of Lammas Wood, a few pieces were found in the next field to the west, and one in the adjacent field to the east. The area lies slightly below the $400 \mathrm{ft}$. contour-line. The pieces are all fairly angulai and comparatively little weathered. Probably over 200 pieces of the rock have been found here from time to time; on December 18, 1906 . I myself found twenty-one pieces scattered over a small space in the central part of the eastern third of the chief field. I have found others on subsequent occasions, but for some years now have not been able to find any more. Mr. Balch, however, reports 